\title{
New microsatellite markers for Myotis daubentonii and Eptesicus nilssonii (Vespertilionidae, Chiroptera)
}

\author{
Dmitriy G. Smirnov*, Sergey V. Titov \& Farid Z. Baishev
}

\begin{abstract}
New microsatellite markers were developed and characterized for two vespertilionid species: three loci for Myotis daubentonii (MmCCA, MdTTA, MdTTTA) and two loci for Eptesicus nilssonii (EnTCA, EnTCTA). The usefulness of these markers were assessed by screening a sample of wing membrane biopsy of 136 specimens of $M$. daubentonii and 206 specimens of E. nilssonii, collected in Samara Province, Penza Province and Khanty-Mansi Autonomous Area (Russia). All the loci were highly polymorphic. Both moderately and highly polymorphic loci were identified with 3-15 alleles segregating per locus (mean in $M$. daubentonii $3.45 \pm 0.29$, in E. nilssonii $6.07 \pm 0.38$ ). The minimal heterozygosity was found in locus MmCCA $\left(\mathrm{H}_{\mathrm{O}}=0.284 \pm 0.034, \mathrm{H}_{\mathrm{E}}=0.305 \pm 0.035\right)$, while all the rest of loci had moderate and high heterozygosity. These polymorphic markers will provide a valuable tool for assessment of population genetics of these two species.
\end{abstract}

KEY WORDS: bats, Chiroptera, microsatellite, Myotis daubentonii, Eptesicus nilssonii.

Dmitriy G. Smirnov [eptesicus@mail.ru], Sergey V. Titov, Farid Z. Baishev, Department of Zoology and Ecology, Penza State University, Krasnaja str. 40, Penza 440026, Russia.

\section{Новые микросателлитные маркеры для Myotis daubentonii и Eptesicus nilssonii (Vespertilionidae, Chiroptera)}

\author{
Д.Г. Смирнов, С.В. Титов, Ф.З. Баишев
}

Разработаны и апробированы три микросателлитных маркера для Myotis daubentonii (MmCCA, MdTTA, MdTTTA) и два для Eptesicus nilssonii (EnTCA, EnTCTA). Эффективность маркеров оценивали путем скрининга образцов ткани (биопсия перепонки крыла) от 136 особей M. daubentonii и 206 особей E. nilssonii, добытых с территорий Самарской, Пензенской областей и Ханты-Мансийского автономного округа России. По всем микросателлитным локусам выявлен высокий полиморфизм. В локусах идентифицировано от 3 до 15 аллелей, где среднее значение для M. daubentonii составило $3.45 \pm 0.29$, а E. nilssonii - 6.07 \pm 0.38 . Минимальная гетерозиготность была обнаружена в локусе MmTGG $\left(\mathrm{H}_{\mathrm{O}}=0.284 \pm 0.034, \mathrm{H}_{\mathrm{E}}=0.305 \pm 0.035\right)$, тогда как по остальным локусам гетерозиготность оценена как средняя или высокая. Результаты анализа показали, что разработанные маркеры могут быть ценным инструментом и успешно применяться при изучении генетической структуры популяций исследованных видов.

КЛЮЧЕВЫЕ СЛОВА: летучие мыши, Chiroptera, микросателлитные маркеры, Myotis daubentonii, Eptesicus nilssonii.

Daubenton's bat Myotis daubentonii (Kuhl, 1817) and northern bat Eptesicus nilssonii (Keyseling et Blasius, 1839) are widespread in Europe. They are nonmigratory bats and thus are convenient models for studying genetic processes in local populations. During the last decade $M$. daubentonii was one of the most popular subjects of such studies. As a result, several microsatellite loci were isolated from the species (Senior et al., 2005; Ngamprasertwong et al., 2008; Atterby et al., 2010; Smith et al., 2011; Laine et al., 2013), part of which were initially were developed for different bat species (Petri et al., 1997; Burland et al., 1998; Castella \& Ruedi, 2000; Kerth et al., 2002; Jan et al., 2012). However, despite the number of available markers,

* Corresponding author wider range of loci is desirable for a number of reasons, including increased power for studies involving individual and family identification, less problems related to "null alleles" and low genetic diversity (Scott et al., 2013). Also, a number of available microsatellite sequences have repetitions, comprised of two nucleotides, or containing palindromic sequences, or non-systemic insertions. The above factors make use of these sequences problematic and unproductive for allele divergence studies. Microsatellite markers for E. nilssonii are described for the first time.

Tissue samples for the study were obtained from 136 individuals of $M$. daubentonii from 14 geographically distant locations and 206 individuals of E. nilssonii from 23 geographically distant locations. Bats were caught in Samara Province, Penza Province and Khan- 
ty-Mansi Autonomous Russia (Russia). All the animals were released at the same point where they were caught after measurements and wing membrane biopsy were taken. Sampling in animals was approved by an institutional animal care and use committee (Sikes et al., 2011).

DNA was extracted from a wing membrane biopsy punch $(\mathrm{d}=5 \mathrm{~mm})$ stored in $96 \%$ ethanol. DNA was isolated on standard methods including homogenization of biomaterial, washing with STE buffer, processing with detergent (SDS, 10\%, pH 7.2), incubation with proteinase $\mathrm{K}$ at $50^{\circ} \mathrm{C}$ over a night, further purification with phenol and chloroform-isoamyl alcohol mix (29:1). Soluted DNA was precipitated with cold absolute ethanol in presence of sodium acetate (3M) (Sambrook et al., 1989).

Microsatellite primers sequences were developed based on the following genomic sequences obtained from the NCBI database: AF203647, AAPE02000001, AAPE02000007, AAPE02000009, AAPE02000023, ALEH01000006, ALEH01000516, and ALEH01011372. Initially there were 12 primer pairs designed and optimized, only five of which produced acceptable for population studies allele polymorphism (Tab. 1).

Polymerase chain reaction (PCR) was carried out using $0.6 \mu \mathrm{m}$ of each primer, $50 \mu \mathrm{m}$ Tris- $\mathrm{HCl}(\mathrm{pH} 8.9)$, $20 \mu \mathrm{m}$ ammonium sulfate, $20 \mu \mathrm{m}$ EDTA, $170 \mu \mathrm{g} / \mathrm{ml}$ bovine serum albumin (BSA), dNTPs cocktail $(200 \mu \mathrm{m}$ of each), $2 \mu \mathrm{m}$ of magnesium chloride, $0.1-0.2 \mu \mathrm{g}$ of DNA and 2 units of Taq polymerase. The thermal profile for all loci was an initial denaturation at $94^{\circ} \mathrm{C}$ for $2 \mathrm{~min}$ followed by 35 cycles of $94^{\circ} \mathrm{C}$ for $30 \mathrm{~s}$, annealing at $60^{\circ} \mathrm{C}$ (primers MmCCA, MdTTA, EnTCA, and EnTCTA) or $62^{\circ} \mathrm{C}$ (primer MdTTTA) for $30 \mathrm{~s}$, and extension at $72^{\circ} \mathrm{C}$ for $1 \mathrm{~min}$. Cycling was followed with terminal extension at $72^{\circ} \mathrm{C}$ for $2 \mathrm{~min}$ (Tab. 1).

PCR products were subjected to electrophoresis in $8 \%$ polyacrylamide gel using Tris-EDTA-borate buffer system. After electrophoresis gels were stained in ethidium bromide solution and visualized in UV-light, graphic images were obtained using BioRad Universal Hood II Imaging system. DNA of Escherichia coli plasmid pBR322, restricted by endonuclease HpaII was used as a molecular weight marker.

Inserts were amplified using PCR followed by sequencing using BigDye v.3.1 dye terminator technology sequenced on an ABI PRISM 3500 DNA Analyser (Applied Biosystems).

Statistical analysis of DNA molecular polymorphism was performed using GenAlEx v.6.0 for MS Excel with identification of observed $\left(\mathrm{H}_{\mathrm{O}}\right)$ and expected $\left(\mathrm{H}_{\mathrm{E}}\right)$ heterozygosity and tested for departure from Hardy-Weinberg equilibrium. Populations were tested for deviations from equilibrium at each locus and across all loci in Arlequin v.3.1 (Excoffier et al., 2005). Bonferroni corrections were applied for multiple comparisons.

In M. daubentonii out of 7 analyzed loci only three were polymorphic, in E. nilssonii out of 5 loci only two were polymorphic. The numbers of discovered alleles as well as expected and observed heterozygosity are summarized in the Table 1.

In $M$. daubentonii, polymorphic loci were with 3-6 alleles (average $3.45 \pm 0.29$ ) and in E. nilssonii with 915 alleles (average 6.07 \pm 0.38 ). In $M$. daubentonii observed heterozygosity $\left(\mathrm{H}_{\mathrm{O}}=0.222-0.833\right)$ was wider than expected $\left(\mathrm{H}_{\mathrm{F}}=0.333-0.583\right)$. In E. nilssonii observed heterozygosity $\left(\mathrm{H}_{\mathrm{O}}=0.143-0.893\right)$ was relatively close to expected $\left(\mathrm{H}_{\mathrm{E}}=0.403-0.847\right)$. Obtained values of observed and expected heterozygosity allow to define certain peculiarities in genetic structure of the studied species. The observed heterozygosity equilibrium for loci MmCCA, MdTTTA, EnTCA, and EnTCTA shows the heterozygote deficiency. Heterozygosity values for MdTTA, in contrary, shows their abundance. The discrepancy between expected and observed heterozygosity in studied loci in $M$. daubentonii could be explained by relatively high gene flow between local populations (migrations) and possible intrapopulation subsidiarity. In general, minimal heterozygosity was observed in locus MmCCA, while in other loci it was moderate or high. Similar results that show discrepancy between expected and observed heterozygosity have been described in other bat species (Vonhof et al., 2002; Trujillo \& Amelon, 2009; Laine et al., 2013).

All loci except MmCCA in one sample, MdTTTA and EnTCTA in three samples, and EnTCA in six samples conformed to Hardy-Weinberg expectations. We found no evidence of linkage disequilibrium between loci among all samples in E. nilssonii. In $M$. daubentonii only loci MmCCA-MdTTA from one sample violated HWE $\left(\chi^{2}=10.4,2 \mathrm{df}, p=0.006\right)$.

The described microsatellite markers allow detailed population genetic studies in $M$. daubentonii and $E$. nilssonii.

ACKNOWLEDGEMENTS. The research was supported by Russian Foundation for Basic Research (grant 15-04-01055a) and by Ministry of Education and Science of the Russian Federation (project 1315 to the Penza State University for scientific research in 20142016). We would like to express our gratitude to Dr. K. Tsytsulina for the help in a translation of article into English. We are grateful to Dr. Marina Kholodova and Dr. Sergei Kruskop for their helpful comments on the early version of the manuscript.

\section{References}

Atterby H., Aegerter J.N., Smith G.C., Conyers C.M., Allnutt T.R., Ruedi M. \& MacNicoll A.D. 2010. Population genetic structure of the Daubenton's bat (Myotis daubentonii) in western Europe and the associated occurrence of rabies // European Journal of Wildlife Research. Vol.56. P.67-81.

Burland T.M., Barratt E.M. \& Racey P.A. 1998. Isolation and characterization of microsatellite loci in the brown long-eared bat, Plecotus auritus, and cross-species am- 


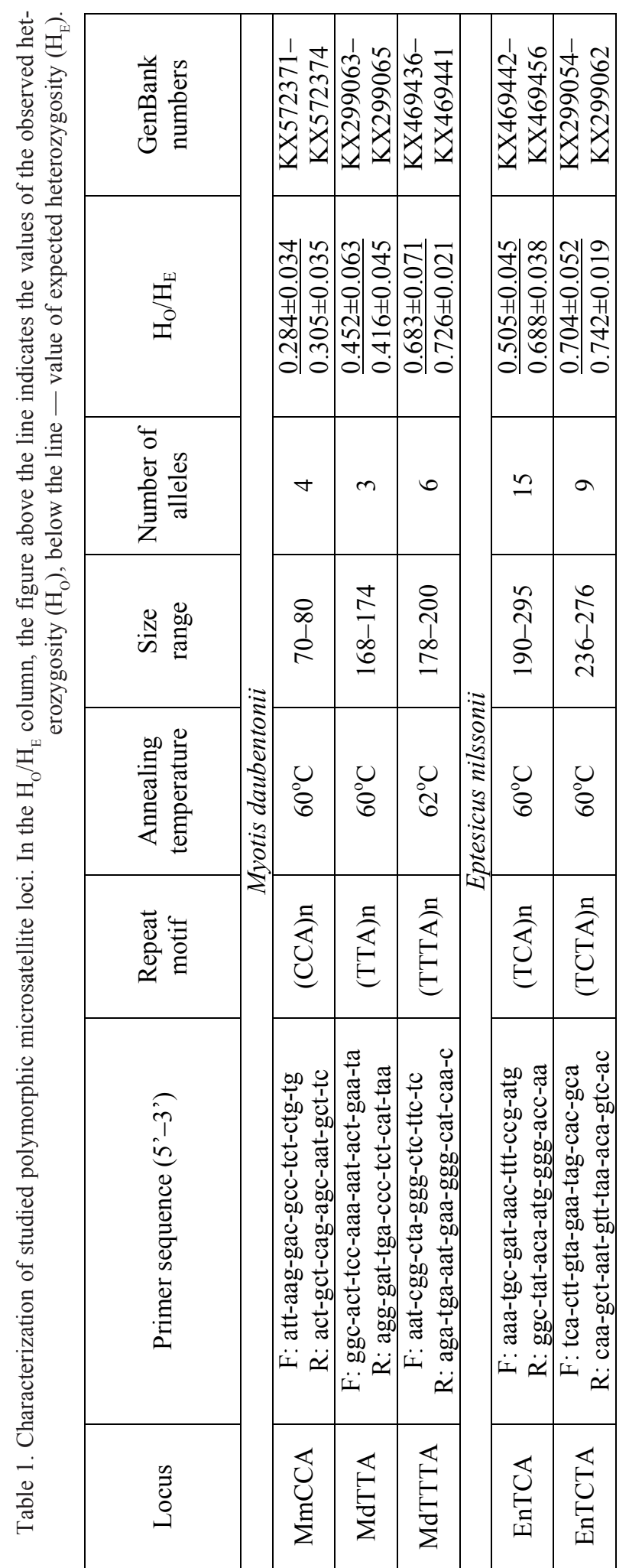

plification within the family Vespertilionidae // Molecular Ecology. Vol.7. P.136-138.

Castella V. \& Ruedi M. 2000. Characterization of highly variable microsatellite loci in the bat Myotis myotis (Chi- roptera: Vespertilionidae) // Molecular Ecology. Vol.9. P.1000-1002.

Excoffier L., Laval G. \& Schneider S. 2005. Arlequin (version 3.0): an integrated software package for population genetics data analysis // Evolutionary Bioinformatics Online. Vol.1. P.47-50.

Jan C., Dawson D.A., Altringham J.D., Burke T. \& Butlin R.K. 2012. Development of conserved microsatellite markers of high cross-species utility in bat species (Vespertilionidae, Chiroptera, Mammalia) // Molecular Ecology Resources. Vol.12. P.532-548.

Kerth G., Mayer F. \& Petit E. 2002. Extreme sex-biased dispersal in the communally breeding, nonmigratory Bechstein's bat (Myotis bechsteinii) // Molecular Ecology. Vol.11. P.1491-1498.

Laine V.N., Lilley T.M., Norrdahl K. \& Primmer C.R. 2013. Population genetics of Daubenton's bat (Myotis daubentonii) in the Archipelago Sea, SW Finland // Annales Zoologici Fennici. Vol.50. P.303-315.

Ngamprasertwong T., Mackie I.J., Racey P.A. \& Piertney S.B. 2008. Spatial distribution of mitochondrial and microsatellite DNA variation in Daubenton's bat within Scotland // Molecular Ecology. Vol.17. P.32433258.

Petri B., Pääbo S., von Haeseler A. \& Tautz D. 1997. Paternity assessment and population subdivision in a natural population of the larger mouse-eared bat $M y$ otis myotis // Molecular Ecology. Vol.6. P.235-242.

Sambrook J., Fritch E. \& Maniatis T. 1989. Molecular Cloning: A Laboratory Manual. New York: Cold Spring Harbor Laboratory Press. 398 p.

Scott D.D., Fitzpatrick S., Bailie D.A., Boston E.S.M., Lundy M.G., Buckley D.J., Teeling E.C., Montgomery W.I. \& Prodöhl P.A. 2013. Isolation and characterization of eight polymorphic microsatellite loci for Natterer's bat, Myotis nattereri (Vespertilionidae, Chiroptera) // Conservation Genetics Resources. Vol.5. P.643-645.

Senior P., Butlin R.K. \& Altringham J.D. 2005. Sex and segregation in temperate bats // Proceedings of the Royal Society, Series B. Vol.272. P.2467-2473.

Sikes R.S., Gannon W.L., \& the Animal Care and Use Committee of the American Society of Mammalogists. 2011. Guidelines of the American Society of Mammalogists for the use of wild mammals in research // Journal of Mammalogy. Vol.92. P.235-253.

Smith G.C., Aegerter J.N., Allnutt T.R., Macnicoll A.D., Learmount J., Hutson A.M. \& Atterby H. 2011. Bat population genetics and Lyssavirus presence in Great Britain // Epidemiology and Infection. Vol.139. P.1463-1469.

Vonhof M.J., Davis C.S., Fenton M.B. \& Strobeck C. 2002. Characterization of dinucleotide microsatellite loci in big brown bats (Eptesicus fuscus), and their use in other North American vespertilionid bats // Molecular Ecology Resources. Vol.2. P.167-169.

Trujillo R.G. \& Amelon S.K. 2009. Development of microsatellite markers in Myotis sodalis and crossspecies amplification in M. gricescens, M. leibii, $M$. lucifugus, and M. septentrionalis // Conservation Genetics. Vol.10. P.1965-1968. 